\title{
A comparative study about mobile learning in Iberian Peninsula Universities: Are professors ready?
}

\author{
Fernando Moreira ${ }^{a}$, Carla Santos Pereirac, Natércia Durão ${ }^{c}$, Maria João Ferreirab,"
}

${ }^{a}$ IJP, REMIT - Universidade Portucalense, Porto \& IEETA - Universidade de Aveiro, Aveiro, Portugal

${ }^{\mathrm{b}}$ Algoritmi - Universidade do Minho and Universidade Portucalense, Porto, Portugal

${ }^{c}$ REMIT - Universidade Portucalense, Porto, Portugal

\section{A R T I C L E I N F O}

\section{Keywords:}

Mobile learning

Professors

Mobile technology

Higher Education Institutions

Iberian Peninsula

\begin{abstract}
A B S T R A C T
Mobile technology is increasingly an element to be considered a paradigm that is changing in education in general, and in higher education in particular. In addition, computers and information technology have increased educational opportunities and have opened the way to new teaching/learning approaches. Due to this, several concepts from the e-learning, m-learning and ulearning appeared. Therefore, it is critical to understand whether users (students and pro- fessors) are receptive and aware to adapt to this new paradigm before deciding to implement teaching learning methods based on mobile technology. Thus, it is necessary to make a funda- mental question "How do professors percept m-leaning?" In this context, the aim of this paper is to investigate the perception of higher education professors in Portugal and Spain (Iberian Peninsula) regarding the m-learning, and to identify the needs of professors as they relate to mobile technologies and how they can be used to promote student's engagement inside and outside of the classroom. The main results obtained allow us to conclude that the majority of Iberian Peninsula professors have knowledge on how to perform the most trivial task with mobile devices and a high results about the utilization of both augmented reality and gamification ap- plications.
\end{abstract}

\section{Introduction}

The world is taking a bigger step when compared with changes found in the education sector. Peter Diamandis predicts that "in 2025, we'll see an acceleration in the rate of change as we move closer to a world of true abundance" (Diamandis, 2015). Moreover, he presented some numbers that illustrate very well what we can expect for the near future. For instance, with a trillion sensors gathering data everywhere (autonomous cars, satellite systems, wearables...), we will be able to know anything what we want, anytime, anywhere, and query that data for answers.

Mobile devices (MD) are transforming citizens lifestyles, adding new dimensions to the concept of socialization, as well as creating new habits (Oulasvirta et al., 2012). Bower et al. (2010) described the opportunities o* ered by these emerging technologies as "creating a new kind of reality, one in which physical and digital environments, media and interactions are woven together throughout our daily lives." According to Cisco's Visual Networking Index (CISCO, 2017) report, in 2021 there will be 12 billion connected mobile devices worldwide and 5.5 billion mobile users worldwide. This technological revolution has followed a trajectory that is manifested, as the numbers presented indicate, a transition from desktop computing to the widespread use of mobile technology. For example, smartphones, according to (Gartner, 2014) in 2018 are expected to reach around 88\% of global mobile device sales.

\footnotetext{
- Corresponding author.

E-mail addresses: fmoreira@upt.pt (F. Moreira), carlasantos@uportu.pt (C.S. Pereira),natercia@upt.pt (N. Durão), mjoao@upt.pt (M.J. Ferreira).
} 
The rapid spread of MD by the world's population is shown by the World Bank Institute (Barbaux, 2006), where the number of people using smartphones increased from less than 700 million in early 2000 to more than 5 billion or $70 \%$ of the world population, in 2010. This precession of lifestyle transformation was already advocated in (Fogg, 2007) when the authors assert that "mobile phones will soon become the most important platform for changing human behavior." On the other hand, it is clear that ubiquitous information systems are transforming the creation and dissemination of information in new ways, creating opportunities in allareas of society (Oinas-Kukkonen and Harjumaa, 2008; Papoutsi and Drigas, 2017), provoking a technological revolution that will profoundly transform the way we live and work.

This rapid evolution complemented by generations of students born with digital technology, leads to having a significantly $\mathrm{di} \square$ erent approach to learning. Because the way they work, entertain and learn is changing rapidly through the opportunities o $\square$ ered by mobile technologies (for example, smartphones, tablets, netbooks), opportunities to integrate physical and virtual, learn from experts in distant places, and choose the time, and the place for such learning to occur (García-Peñalvo FJ et al., 2017; Fonseca et al., 2014). In this context, students are used to have access to multiple sources of information in real time, running multitasking, socially connected with their peers via MD, leading to necessary new solutions compared to current teaching-learning processes (TLP). With this growth, we would expect further evolution of the concepts of learning, particularly in higher education institutions (HEI), once these institutions have gone through rapid changes, especially during the last 10 years (The World Bank Institute, 2012). The nature of higher education has greatly changed due to the rapid development of mobile computing devices and Internet resources (Liaw et al., 2010). In addition, computers and information technology have increased educational opportunities and have opened the way to new teaching/learning approaches. Due to this, several concepts from the e-learning, m-learning and ulearning (Hürsen et al., 2011) appeared. MDs are also useful tools that go everywhere; this will be ideal for any student during the learning process. UNESCO considered MDs as a platform to enable equal opportunities in education between di $\square$ erent countries (West and Ei, 2014). However, it was expected that the concept of mobile learning (m-learning) had a greater evolution, because both students and professors are more enlightened technology (Severino and Messina, 2010). Mobile learning technologies eradicated geographical boundaries, enabling cooperative learning environments. In addition, the possibility of learning anywhere, at any time, fits well into a lifelong learning framework (Holzinger et al., 2005).

Among the several research papers (Research, 2012) (Moreira et al., 2016) on the use of mobile technology in higher education indicate that students are currently leading the implementation of MD in learning tasks. Gikas and Grant (2013) indicated that mobile technology has become an integral part of the educational process at HEIs as it brings many opportunities and challenges for students and professors. In this context, when mobile learning (m-learning) is integrated with the various HEIs systems (LMS, ...) it provides learning anywhere, anytime. Generally, mobile technology helps students to increase their technological awareness, from simple participation in chats, participation in social networks, finding answers to their questions, facilitating team collaboration (collaborative learning (Cheon et al., 2012)), share knowledge and, as a consequence, improve their learning outcomes. In particular, $\mathrm{m}-$ learning can help students with special educational needs and motivate them to attend classes remotely with the help of their MDs.

Mobile learning allows professors and students to learn through ways that were not possible in the past. The ways in which multifunctional MDs can shift students from formal learning and open space for learning to be conceptualized in a wide variety of places, times and forms. It is within this context of rapid and sustained change that HEIs have a responsibility to prepare students to be productive members of society in the future, capable of accepting the demands of new contexts of work and personal life. Students no longer rely solely on traditional teaching approaches (Papert, 1994) in formal spaces designed for the needs of yesterday's society. They also need to be able to learn through new and flexible ways that prepare them to function well in tomorrow's world.

The ubiquity of MDs combined with technological developments such as geospatial and motion detection, augmented reality, and contextual awareness (Johnson et al., 2014), is providing an additional stimulus for professors to re-adjust both approaches, pedagogical and practices (Schuck et al., 2013). However, TLPs in HEIs still appear to be anchored in past forms of conducting educational activities (Royle et al., 2014).

The students of HEIs have mobile technologies and Internet access in and out of institutions. These technologies have enabled access to resources related to their studies allowing them the framework for m-learning scenarios (Severino and Messina, 2010). However, these two factors are some of the factors that allow mobile learning to develop. As learning is a subjective construction in which students must be fully involved, Spiegel and Rodríguez (2016) raises the question "Which are the necessary requirements to let mobile technologies for tools become their task of studying and building knowledge?". According to (Park, 2011) and (Moreira et al., 2016) for the learning potential it is required the occurrence a set of factors that have to be articulated, including the professor's role (Spiegel and Rodríguez, 2016).

Before thinking of designing and implementing a m-learning system, it is important to check the perception of future users regarding m-learning since its perception, which will influence their willingness and readiness to use the system (Levy, 1996). In Morris (2010) it is shown that today's professors have di $\square$ culties in being familiarized with the digital language of their students, making it di $\square$ cult to maximize their learning through models implemented through m-learning. Thus, there is a need for qualified professors in m-learning models. As a result, the successful integration of m-learning technologies in education require the perception of these technologies by professors, so it is possible to ask the question "How do professors percept m-learning?" In this context, the aim of this paper is to investigate the perception of professors in higher education, the area of technology in Iberian Peninsula (IP) in relation to m-learning, and to identify the needs of professors as they relate to mobile technologies and how they can be used to promote student's engagement inside and outside of the classroom. For this the quantitative research methodology is used.

The paper is structured as follows. Section 2 critically examines the m-learning and the relationship between the m-learning and professors. Section 3 presents the state of the art of m-learning in the perspective of HEI professors. Section 4 presents the research methodology. Section 5 summarizes the results and discussion of the research and finally, Section 6 presents the study conclusions 
Table 1

m-learning definitions.

\begin{tabular}{|c|c|c|c|}
\hline Year & Author & Definition & Reference \\
\hline 2000 & Quinn & "a type of elearning through mobile devices" & Quinn (2000) \\
\hline 2003 & Homan and Wood & $\begin{array}{l}\text { "the technology that changed the way the students communicate, interact, and behave with } \\
\text { each other and their perceptions towards their learning" }\end{array}$ & Homan and Wood (2003) \\
\hline 2004 & Mirski and Abfalter & "a specific topic that is emerging form distance learning" & Mirski and Abfalter (2004) \\
\hline 2005 & O'Malley et at. & $\begin{array}{l}\text { "learning that takes place when the student benefits from the opportunities provided by } \\
\text { mobile technologies" }\end{array}$ & O'Malley et al. (2005) \\
\hline 2007 & Traxler & $\begin{array}{l}\text { "an educational interaction delivered through mobile technology and accessed by learners } \\
\text { from any location" }\end{array}$ & Traxler (2007) \\
\hline 2008 & Mcconatha, Praul and Lynch & $\begin{array}{l}\text { "the learning that is employed through the use of small computing mobile devices. This } \\
\text { definition includes smartphones and small handheld device" }\end{array}$ & Mcconatha and Praul (2008) \\
\hline 2010 & El-Hussein and Cronje & $\begin{array}{l}\text { "any type of learning that takes place in learning environments and spaces that take account } \\
\text { of the mobility of technology, mobility of learners and mobility of learning" }\end{array}$ & El-Hussein and Cronje (2010) \\
\hline 2012 & Park, Nam, and Cha & $\begin{array}{l}\text { "any educational provision where the sole or dominant technologies are handheld or palm- } \\
\text { top devices" }\end{array}$ & Park et al. (2012) \\
\hline 2012 & Kinash et al. & "the use of mobile devices with an internet connection for educational setting" & Kinash et al. (2012) \\
\hline 2013 & Crompton & $\begin{array}{l}\text { "learning across multiple contexts, through social and content interactions, using personal } \\
\text { electronic devices" }\end{array}$ & Crompton (2013) \\
\hline 2013 & Matias e Wolf & $\begin{array}{l}\text { "is not only the learning that is based on the use mobile devices but also the learning that is } \\
\text { mediated across multiple contexts using portable mobile devices" }\end{array}$ & Matias and Wolf (2013) \\
\hline 2014 & Emran and Shaalan & $\begin{array}{l}\text { "facilitates knowledge sharing among students and educators while interacting with each } \\
\text { other" }\end{array}$ & Emran and Shaalan (2014) \\
\hline 2017 & $\begin{array}{l}\text { Al-Hunaiyyan, Al-Sharhan, } \\
\text { and Alhajri }\end{array}$ & $\begin{array}{l}\text { "is a learning strategy that provides students with the 21st century learning capabilities in } \\
\text { order to enable them to utilize a wide range of the portable computing devices" }\end{array}$ & $\begin{array}{l}\text { Al-Hunaiyyan and Al- } \\
\text { Sharhan (2017) }\end{array}$ \\
\hline
\end{tabular}

and 7 presents the study limitations and future work.

\section{Background}

\section{1. m-learning}

Mobile learning (m-learning) can be considered as the natural evolution of e-learning with more e $\square$ ective communication, with powerful and personalized mechanisms (Mostakhdemin-Hosseini and Tuimala, 2005; García and Esteban, 2011), or a new distance learning platform (Georgiev and Georgieva, 2004; Zhuang et al., 2011). This new way will allow any student of any age, from any school level, to study and access learning materials anytime, anywhere.

Sharples (2007), show that it is necessary to take into account: (i): the user's involvement with these mobile technologies, because the assumption is to have students moving from one space to another (classroom, library, public transport, etc.) and topic to topic; (ii) understanding that learning can occur outside of formal settings; and (iii) it is an active process of building knowledge and skills through practice within a group or community.

However, it is necessary to discuss a formal definition of m-learning and in the literature; m-learning has been defined from di $\square$ erent perspectives, as can be seen in Table 1, where a chronological evolution of the various definitions is presented.

Based on the definitions presented earlier, we chose to use the definition presented in (Al-Hunaiyyan and Al-Sharhan, 2017), by considering the need for students to acquire skills for the 21st century (World Economic Forum, 2016). These competencies, according to (World Economic Forum, 2016) are: "(i) Foundational Literacies (How students apply core skills to everyday tasks); (ii) Competencies (How students approach complex challenges); (iii) Character Qualities (How students approach their changing environment)." M-

learning is the research trend in the field of education that addresses mobility in di $\square$ erent dimensions: (1) technology mobility, (2) student mobility, (3) teacher mobility and learning mobility (Al-Emran and Shaalan, 2015). In the first case it is possible to include hardware (mobile phones, smartphones, tablets and laptops) and software (repositories with applications that are specifically designed for learning purposes). In addition, the MDs have increasingly evolved capabilities because they allow the use of sensors, cameras, oscilloscopes, GPS for localization and maps and the use of generic applications such as social networks, web search, augmented and virtual reality, with possibilities to be adapted for educational purposes to stimulate learning within and outside the classroom (Newhouse et al., 2006). The mobility of students and professors is directly related to the fact that today all have one or more MDs and are connected to the Internet either through HEIs wireless networks or through data plans provided by telecom operators. The learning mobility has to be framed, second (Ozdamli, 2012) in an educational context of mobile learning according to the new trends in technology development. The result of the study presented in (Ozdamli, 2012) was: integration tools, pedagogical approaches, assessment techniques and teacher training.

The construction of an m-learning environment, according to (Al-Hunaiyyan and Al-Sharhan, 2017) requires the following resources:

- Portable devices;

- 21st century learning competencies; 
- Accessibility through connectivity Medium (Internet or Network);

- Smart classrooms components (smart interactive board, Audio/video components, class management system, etc.);

- Interactivity and Collaboration;

- Interactive educational content;

- Controlled collaborative learning environment (closed loop).

In summary, according to (Al-Hunaiyyan and Al-Sharhan, 2017) m-learning helps students and professors to perform theirdaily tasks in a short period of time through the use of MDs (tablets or smartphones), with flexible "time-space" configurations, creating opportunities for new ways of designing and implementing learning, "all the time, everywhere," learning "on the move," and "multiple contexts."

\subsection{Advantages and disadvantages of m-learning}

The literature shows that m-learning has associated itself with numerous benefits, both from an educational and technological point of view. In this context, according to Miangah and Nezarat (2012) the learning process can be personalized, omnipresent, spontaneous and informal, as well as practical and inexpensive (Cheon et al., 2012). According to Snell and Snell-Siddle (2013) mobile technologies help professors and students easily communicate, share and coordinate projects.

With respect to the use of mobile technologies allied to teaching, Valero et al. (2012) point to the benefits of portability, immediacy, connectivity, ubiquity and adaptability. Allowing for greater collaboration among students, knowledge creation and skills, and better interaction and communication between teacher and student (Jackson, 2016). In this context, according to (Sabah, 2016) students perceive m-learning as an e $\square$ ective learning supplement that motivates, stimulates interaction and improves their learning process. In general, studies show that most students are satisfied with the approach proposed by m-learning and are ready to integrate it into existing pedagogies, since m-learning allows access to any type of information (anything) (Development, 2011), anytime, anywhere (Brand and Kinash, 2010).

In addition to the benefits presented, a paradigm shift can be observed in the teaching-learning process in which the student starts to conduct his own learning using technology more e $\square$ ectively, with the teacher having a role to tutor learning (Boticki et al., 2015; Land and Zimmerman, 2015; Miangah and Nezarat, 2012). The m-learning implemented e $\square$ ectively adds value to the existing learning approach, it allows students to check the flexibility and interaction of students, and creates a collaborative learning environment (Sabah, 2016), allowing students to access learning content (for example, learning materials, tests, dictionaries). Besides allowing conducting sequencing of a personalized curriculum according to their learning needs.

In short, m-learning has been recognized as one of the most influential approaches to education (Johnson et al., 2012). However, in the context of higher education m-learning is not a widespread practice, since it is still at a stage that may be called the test phase (Barreh and Abas, 2015). According to Sabah (2016) for m-learning to succeed, it is necessary to identify the factors that influence student acceptance and adoption.

Clearly, there are many initiatives to use m-learning approaches for educational purposes, but academic and professional research available on this topic is still limited, thus providing an untapped area for research activities.

Despite the advantages identified in the literature and presented here, however, there are always contrasting scenarios in all contexts, including m-learning (Biloš et al., 2017), such as student performance, known to be " $e$ $\square e c t i v e$ ", be disappointing or can even adversely a $\square$ ect students if they do not have a proper treatment Chu (2014).

From the point of view of mobile technologies in combination with the student perspective, in terms of limitations, unreliable and unsafe Internet connection, small size keyboard and screen, limited memory and battery capacity, di $\square$ cult to navigate and download on mobile devices, in particular smartphones. These limitations can cause negative behavioral intent and lead students to reject the actual use of m-learning (Sabah, 2016). From the above it can be verified that the mobile limitations are one of the main obstacles that $\mathrm{a} \square$ ect the perceived ease of use and the behavioral intention of the students to join m-learning in a spontaneous way.

\subsection{M-learning and professors}

Based on the principle that the use of MDs in education in general, and HEIs in particular, is unavoidable, the relationship that professors have with the introduction of new technologies is always an interesting issue to discuss. Koc (2013) presents a research paper on how professors beliefs about technology in teaching a $\square$ ect their motivation to implement innovations. In this study, he identified that professors, in describing technology and its use in education, used metaphors that reflected their beliefs, such as: (i) a phenomenon in continuous development; (ii) facilitation, by extension of human capacity; (iii) vital need; (iv) power representation; and (v) threat. Technology-related beliefs show that professor perceptions go beyond associations to technical or instrumental aspects, and human, social, cultural and political aspects must also be taken into account (Koc, 2013).

Based on these beliefs and the need to perceive the di $\square$ culty of the relationship between the application of technology and the real application of technology in TLPs, it forces professors to be open to change. On the one hand, professors need to acknowledge and accept that students are now used to a changing world, and on the other hand, they have to be able to adopt new strategies in the TLPs that meet 21st century skills (World Economic Forum, 2016), in training.

As mobile technologies continue to proliferate and diversify their pedagogical potentialities, there has been a tendency for professors to continue to adopt traditional teaching approaches in formal or virtual environments (Norris et al., 2013), focusing on approaches and teacher-oriented and content delivery, as indicated by Cochrane and Antonczak (2014) "traditional pedagogical 
strategies and pre-existing course materials onto mobile devices and social media" and by Royle et al. (2014) "delivery systems for teaching or training content as much as they are seen as digital tools for learning embedded into the fabric of people's lives". In this context, professors should select the most appropriate tools for the TLPs and actively use them for activities that are developed within and outside the classroom. However, according to Corbeil and Valdes-Corbeil (2007), frequent use of MDs does not mean that students or professors are ready for m-learning. In Ozdamli and Uzunboylu (2015) it is shown that it is not enough to integrate technology into education without a proper way of how technology should be used in TLP, because technology alone does nothing to improve pedagogy (Ergüt and Altıntas, 2012; Fiscarelli and Bizelli, 2013; Kok, 2012; Tayfun and Arzu, 2012).

Alwraikat and Tokhaim (2014) present a study on professors attitudes towards m-learning, where they show a very interesting set of results from various perspectives. The attitudes of female professors were more positive in relation to m-learning than that of male professors. However, the study presented in (Uzunboylu and Ozdamli, 2011) presents completely opposite results. Another dimension studied was related to the professional category (Assistant Professor, Associate Professor, Full Professor), with the resultsindicating that younger professors presented a more positive attitude towards m-learning than professors with a higher professional category. Finally, the studied dimension is directly related to the di $\square$ erence of attitude of professors in relation to m-learning and the academic experience. The results showed that the attitudes of professors with 21 years of experience or more were more positive than the younger ones, which is in contradiction with previous results.

The importance of perceptions, both by students (Jairak and Praneetpolgrang, 2009; Liaw et al., 2010; Moreira et al., 2016), and by professors (Moreira et al., 2017) on the use of m-learning applications has been focused and analyzed in di $\square$ erent studies. These studies highlight the acceptance of mobile learning given the ease and capacity to use without time and location restrictions. However, it is necessary to look at several aspects of m-learning applications, namely the technical capacity of mobile devices, the expectations and capacities of students and professors, as well as the e $\square$ ectiveness of the tools in terms of the teaching-learning process.

\section{State of the art}

As previously discussed, the m-learning o $\square$ ers students and professors unique features that did not exist in traditional learning platforms, for example, in e-learning. One of the most interesting features is that the mobility refers to the perspective to have flexibility in terms of time, location, time and space that cannot be taken when training is from another type (Yusri et al., 2015). The second important feature, and possible with m-learning, is collaborative learning, because the use of MD with Internet access inside and outside the classroom, will enable students to interact in a more easily, with other students and professors in di $\square$ erent physical locations.

The features discussed above in relation to the participation of professors in this process are already the subject of several researches (Corbeil and Valdes-Corbeil, 2007). The authors present a study with a review of research on mobile learning in teacher education where 37 papers were analyzed. In addition to works found in (Corbeil and Valdes-Corbeil, 2007), other studies show some results concerning this subject.

In (Andrews et al., 2011) a research work on the perception of professors in Indonesia in relation to m-learning is presented to determine their willingness to participate in the use of m-learning in teaching. The obtained results show that Indonesian professors have a positive perception regarding the use of m-learning.

The study presented in (Baran, 2014) can be interpreted by the m-learning, from the perspective of professors, has a positive $\mathrm{e} \square$ ect on student motivation for learning mathematics. And the relationship between m-learning and a variety of teaching/learning ap- proaches is positive and significant.

In (Yusri et al., 2015) the authors have presented the results of a detailed and systematic investigation into the critical success factors a $\square$ ecting user perception of m-learning from the perspective of professors. As a result, the professors are one of the crucial user groups, so it is important to understand the factors they consider crucial for the success of mobile learning. The results showed that none of the factors analyzed were statistically significant.

US-based study presented in (Taleb et al., 2015) realized that another reason why the HEIs are not receptive to the adoption of mlearning is because students would use the devices to socialize and not to perform tasks related to the TLP and, so most professors prohibited the devices in the classroom.

Uzunboylu and Ozdamli (2011) presented a study which shows that the success of m-learning integration in education requires first, to be determined the perception of professors regarding the technology to be used. The problems that the authors found were the lack of an instrument to do the evaluation of the teacher's perception. The result of the study showed that professors in Cyprus have average levels of perception regarding adoption of m-learning.

The study presented by Jackson (2016) had as goal to explore the impact of m-learning devices like iPhone and tablets on postgraduate researchers ability in order to engage positively in the research community.

Cheng (2015) carry out a study from Taiwanese mobile phone users; in a total of 750 questionnaires, and 486 usable questionnaires were analyzed in this study, with a usable response rate of $64.80 \%$. The results of the study shown that learners could judge m-learning by how well it meets their perceived compatibility of m-learning, and they regard m-learning as a useful, easy to use, and enjoyable tool if they can explore it themselves through the content and interface screens over the mobile-based learning environments at any time in any location.

Ken et al. (2017) presents a research study with one hundred and forty-four refereed journal articles in the period from January 2010 to December 2015 in order to examine the longitudinal trends of mobile learning through using text mining techniques in a more comprehensive manner. To the authors the research gives a bigger picture on how importance of m-learning as it gains more 
and more attention from all over the world due to the proliferation of country that have embarked on this new and trendy paradigm of teaching and learning method in education fields.

Biloš et al. (2017) presents a research of the current status of mobile device usage and mobile learning adoption in vocational education and training (VET) secondary schools in three European Union countries - Austria, Czech Republic, and Germany. From this study it was concluded that Smartphones and laptops were the most commonly used devices. But, the most of participants perceived themselves as advanced users of mobile devices, but reported a shortage of mobile learning experience with ICT support.

The number of papers on the applicability of m-learning from the professors' point of view is reduced globally, and it was verified that does not exist papers relating to HEIs in Portugal and Spain. After the survey conducted during the period of 2009-2016 and using the following query search: "(professors OR professors) AND (mobile learning OR m-learning OR Mobile Learning OR M-learning) AND Portugal AND Spain", it was the inexistence of any paper. In this context, from this study it was possible to conclude that there is no comparative study on mobile technologies in education, particularly in Iberian Peninsula (IP) HEIs, thus making it relevant and justified.

\section{Research methodology}

The purpose of this section is to describe the procedures used to collect data that are the basis for this research. The main feature of the scientific method is an organized research, strict control of the use of observations and theoretical knowledge.

For the present study, we used the methodology of quantitative research, since it is more appropriate to determine the opinions and attitudes of the respondent based on structured questionnaires. In this approach, data is collected through structured questionnaires and clear goals.

The undertaken study was descriptive in nature. Data collected for quantitative research through the use of questionnaires requires special care because it is not enough to collect responses about the issues of interest, it is also important to know how to do statistical analysis for proper results validation. Aspects such as the sample size, the way the questionnaire is prepared, the questions formulation, data analysis, error margins, the selection of individual process of who should compose the sample, among other things, are important and they should be taken into account for any investigation (Campenhoudt and Quivy, 2008). This method is recommended when you want to know a population, to analyze social phenomena and, in cases where it is necessary to inquire a big number of people about a certain subject. The questionnaire before being delivered was subjected to the evaluation of four experts in the field.

The aim of this study is to investigate the perception of professors in higher education, the area of technology in IP HEIs regarding to m-learning, and to identify the needs of professors as they relate to mobile technologies and how they can be used to promote student's engagement inside and outside of the classroom. The quantitative study was based on an online questionnaire with 6 sections (Demographic information, Prior knowledge, Participation/Engagement, Use of Mobile Devices, Mobile use in the classroom and Self-e $\square$ cacy) and 41 questions (Q1-Q41). The first section consists of 6 questions, which include, for example, the age and gender. Second section contains a question (Q7) with 11 items about the information that the professors know about MD. The third section contains 18 questions about their opinion of Participation/Engagement of the students in the use of MD in activities inside and outside of the classroom. As for the fourth section, it contained a question with 18 items about how to use MD in the classroom. In section five we ask 14 questions about using MD in the classroom. Finally, in the last section we have 3 questions about self-e $\square$ cacy. Almost all questions were close-ended type. Sections 2 and 4 use nominal scale (Yes (1)/No (0)). Section 3 use five-point Likert scale ranging from "Strongly Disagree" (1) to "Strongly Agree" (5) and Section 5 in the first 12 questions.

The questionnaire has been online for 60 days and 70 valid responses were received ( 37 from Portugal and 33 from Spain). Data collected were pooled and treated by using the IBM SPSS Statistics 24.0 software. Statistical analyses used for the data analysis were descriptive analysis (frequency analysis, descriptive measures and graphical representations), reliability analysis (Cronabach's Alpha), and principal component analysis with optimal scaling (CATPCA).

\section{Analysis and discussion of results}

The study sample consists of 70 professors (37 Portuguese and 33 Spanish) from the area of technology in IP HEIs. Most respondent's gender were male $(67,1 \%)$ whereby, the majority of professors $(55,7 \%)$ were aged between 41 to 50 years old (see Fig. 1).

Given that the age group of professors is equivalent in both countries (Fig. 2), and considering that they can simultaneously teach various levels of teaching degrees, we find interesting to analyze teach program by country (see Fig. 3). We can conclude that

Portuguese professors teach in a higher proportion the master's degree (78.4\%), than the Spanish professors (57.6\%). While Spanish professors teach a higher degree $(90.9 \%)$ than Portuguese professors $(73 \%)$. We conclude that, in relation to the doctorate, the proportion is identical for the professors of the two countries (Fig. 4).

In order to verify if the variability of the answers resulted from the di $\square$ erences between the opinions of each professor, we performed a reliability analysis to verify the existence of internal consistence measured by Cronbach's Alpha. The value of alpha varies from 0 to 1 and higher values of alpha are more desirable. Table 2 shows the results of Cronbach's Alpha for evaluate four dimensions (sections), which are "Prior Knowledge" (Dimension 1), "Participation/Engagement" (Dimension 2), "Use of Mobile Devices" (Dimension 3) and "Mobile use in the classroom" (Dimension 4).

As can be observed, the Cronbach's Alpha coe $\square$ cients for dimensions 1 and 3 lies between 0,8 and 0,9 which is considered good and for dimensions 2 and 4 are excellent because exceed 0,9 (Pestana and Gageiro, 2014). Therefore, all dimensions in this study were deemed to be reliable. Thus, it makes sense to present the descriptive results (percentages, mean and standard deviation (sd), 


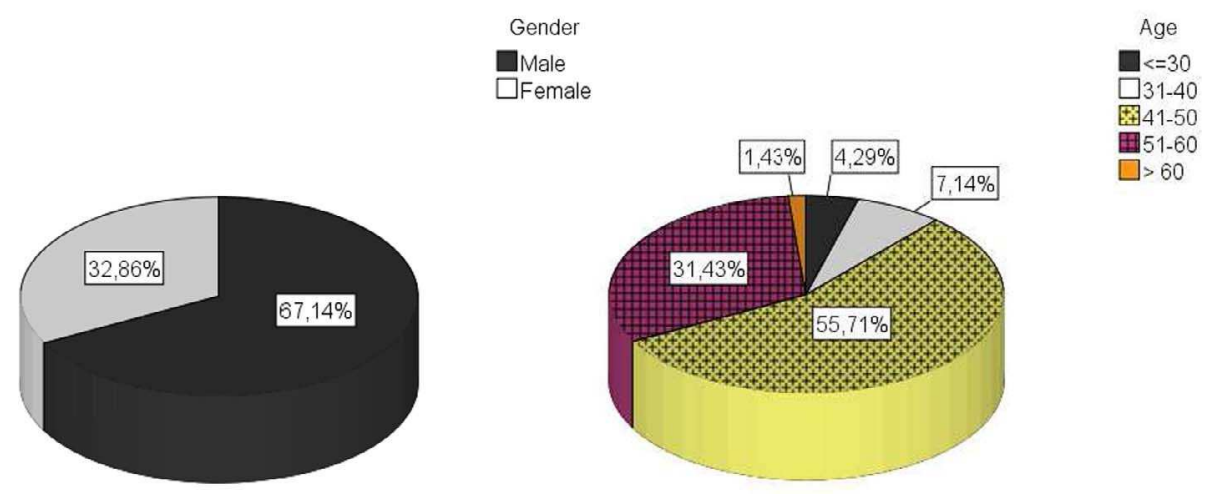

Fig. 1. Pie charts for Professors Age and Gender.

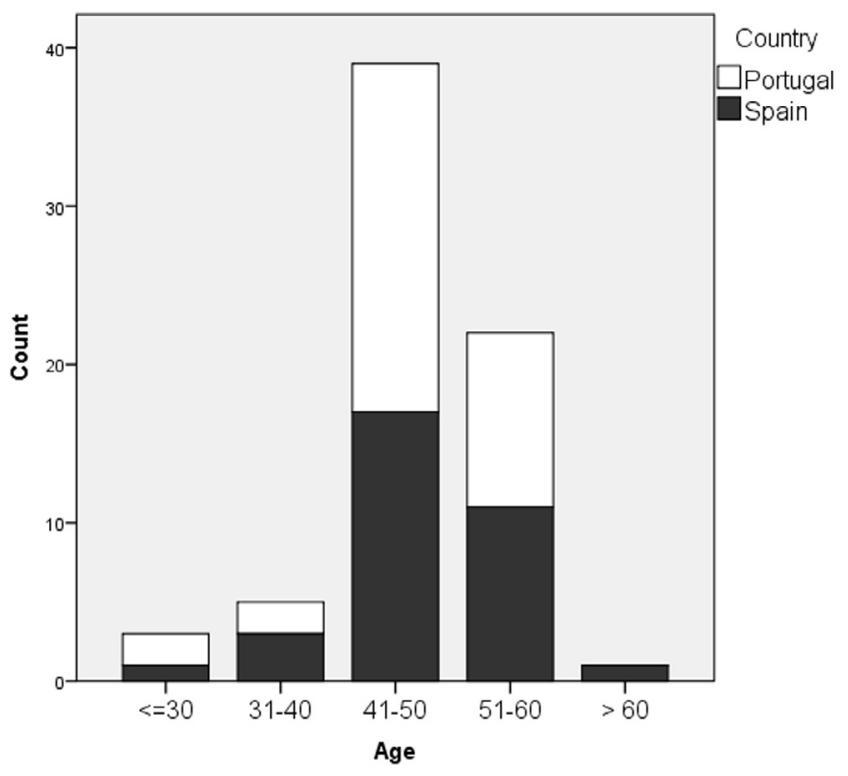

Fig. 2. Bar chart for Professors Age by country.
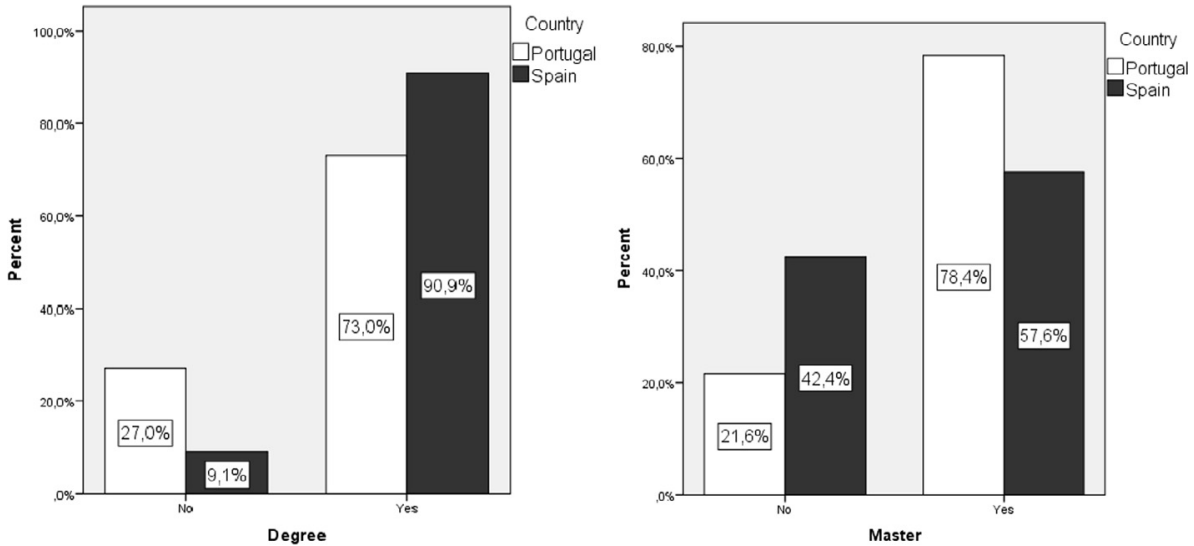

Fig. 3. Bar chart for Professors teaching degrees by country.

according to measurement scale) for each question/item. The results of the analysis can be found, resumed, in Tables 3-6 (Dimension 1 to Dimension 4 , respectively).

When it comes to the matter of "Prior Knowledge", the knowledge of professors in both countries is equivalent. Table 3 shows the 


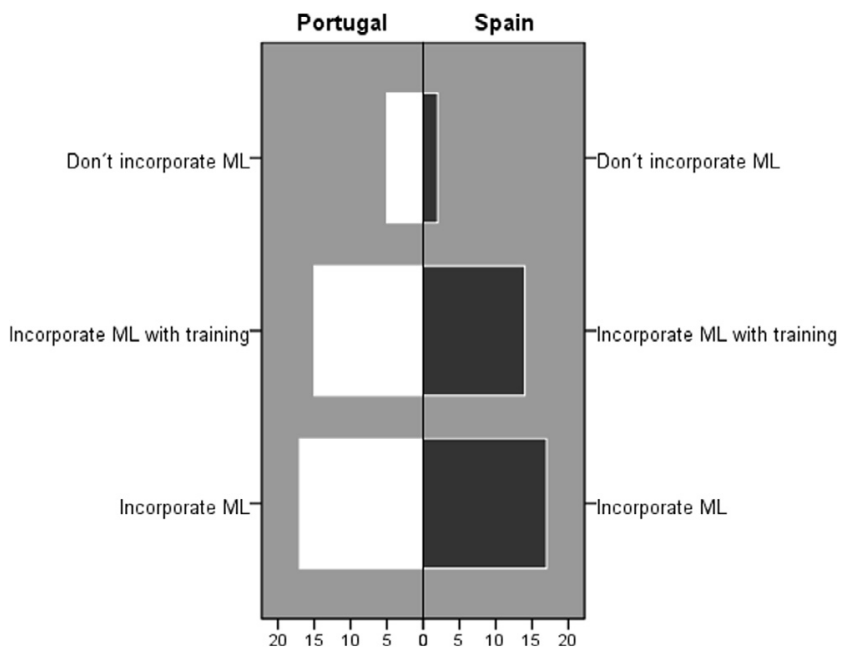

Fig. 4. Bar chart for incorporating ML in classroom by country.

Table 2

Cronbach's Alpha coe $\square$ cients.

\begin{tabular}{lll}
\hline Dimension & Cronbach's Alpha & $\mathrm{N}^{\circ}$ of Items \\
\hline 1. Prior Knowledge & 0,863 & 11 \\
2. Participation/Engagement & 0,912 & 18 \\
3. Use of mobile devices & 0,869 & 15 \\
4. Mobile use in the classroom & 0,912 & 10 \\
\hline
\end{tabular}

Table 3

Percentages of Yes and No responses of the 11 items of "Prior Knowledge" (IP).

\begin{tabular}{|c|c|c|c|}
\hline \multicolumn{3}{|c|}{ I know how to... } & \multirow{2}{*}{$\begin{array}{l}(\mathrm{P} / \mathrm{S})(\%) \\
0,0 / 6,1\end{array}$} \\
\hline 1 & Connect to and access the internet from a MD & No & \\
\hline & & Yes & $100 / 93,9$ \\
\hline \multirow[t]{2}{*}{2} & Download music and video files on a MD & No & $10,8 / 14,3$ \\
\hline & & Yes & $89,2 / 81,8$ \\
\hline \multirow[t]{2}{*}{3} & Find the definition of a word or concept on a MD & No & $8,1 / 6,1$ \\
\hline & & Yes & $91,9 / 93,9$ \\
\hline \multirow[t]{2}{*}{4} & Download a mobile application on a MD & No & $2,7 / 9,1$ \\
\hline & & Yes & $97,3 / 90,9$ \\
\hline \multirow[t]{2}{*}{5} & Interface or connect my calendar/alarm on a MD & No & $18,9 / 6,1$ \\
\hline & & Yes & $81,1 / 93,9$ \\
\hline \multirow[t]{2}{*}{6} & Translate a sentence into another language on a MD & No & $13,5 / 9,1$ \\
\hline & & Yes & $86,5 / 90,9$ \\
\hline \multirow[t]{2}{*}{7} & Access and participate in a social network site on a MD & No & $10,8 / 12,1$ \\
\hline & & Yes & $89,2 / 87,9$ \\
\hline \multirow[t]{2}{*}{8} & Send and receive emails/text messages on a MD & No & $5,4 / 0,0$ \\
\hline & & Yes & $94,6 / 100$ \\
\hline \multirow[t]{2}{*}{9} & Access college resources such as LMS, payroll, etc., on a MD & No & $18,9 / 33,3$ \\
\hline & & Yes & $81,1 / 66,7$ \\
\hline \multirow[t]{2}{*}{10} & Download augmented reality applications on a MD & No & $29,7 / 36,4$ \\
\hline & & Yes & $70,3 / 63,6$ \\
\hline \multirow[t]{2}{*}{11} & Download Mobile App Gamification on a MD & No & $29,7 / 39,4$ \\
\hline & & Yes & $70,3 / 60,6$ \\
\hline
\end{tabular}

P - Portugal; S - Spain.

results of percentages of "Yes" and "No" responses of the 11 items of question Q7.

We note that the majority of IP professors have knowledge on how to perform the most trivial tasks (such as "connect and access internet" "download a mobile application on a $M D^{\prime}$ ", etc...) with percentages above $80 \%$. Although still very high (> $60 \%$ ), we found a decrease when the prior knowledge is related to download augmented reality applications and Mobile App Gamification on a MD (items 10 and 11), for professors of both countries. However, it is curious to note that in relation to "Access college resources such as LMS, payroll, etc., on a MD", while in Portugal this figure is above $80 \%$, in Spain it is only $66.7 \%$. 
Table 4

Descriptive Statistics for each question of "Participation/Engagement" by country (Portugal/Spain).

\begin{tabular}{|c|c|c|}
\hline Question & Mean (P/S) & $\mathrm{sd}(\mathrm{P} / \mathrm{S})$ \\
\hline Q8 - My students would be more likely to participate in classes if they could use their MD & $3,54 / 3,45$ & $1,04 / 1,03$ \\
\hline Q9 - Mobile learning opportunities would allow students to learn and study in places they normally couldn't & $4,35 / 3,94$ & $0,72 / 0,79$ \\
\hline Q10 - It would be easier for students to complete classwork and assignments if they could use MD & $3,57 / 3,00$ & $1,28 / 0,90$ \\
\hline Q11 - My students would spend more time on classwork if they could access materials anytime, anywhere on their MD & $3,32 / 2,88$ & $1,16 / 0,86$ \\
\hline $\begin{array}{l}\text { Q12 - My students would be more likely to participate in class activities outside of the class time if they could do that through their } \\
\text { MD }\end{array}$ & $3,62 / 3,45$ & $1,09 / 0,94$ \\
\hline Q13 - My students would be more likely to engage in class discussions inside of class they could post their thoughts from their MD & $3,65 / 3,45$ & $1,11 / 1,15$ \\
\hline Q14 - My students would be more likely to engage in class discussions outside of class they could post their thoughts from their MD & $3,95 / 3,61$ & $0,91 / 1,17$ \\
\hline Q15 - My students would be more likely to ask for help if they could communicate through their MD & $3,65 / 3,64$ & $1,11 / 1,06$ \\
\hline Q16 - Mobile learning could be incorporated into classes & $3,97 / 4,03$ & $0,83 / 0,98$ \\
\hline Q17 - Augmented reality could be incorporated into ML classes & $4,00 / 3,73$ & $1,08 / 1,04$ \\
\hline Q18 - Gamification could be incorporated into ML classes & $4,08 / 3,73$ & $1,01 / 0,98$ \\
\hline Q19 - Students should be able to easily view course materials on their MD & $4,38 / 4,39$ & $0,79 / 0,66$ \\
\hline Q20 - Students should be able to download mobile applications that could help them study & $4,59 / 4,33$ & $0,55 / 0,85$ \\
\hline Q21 - Students should be able to access LMS (e.g. Moodle..) in a mobile format on their MD & $4,59 / 4,30$ & $0,64 / 0,85$ \\
\hline Q22 - Students should be able to take quizzes on their MD & $4,30 / 4,06$ & $1,05 / 0,86$ \\
\hline Q23 - Students should be able to participate in discussion forums from their MD & $4,54 / 3,97$ & $0,65 / 1,07$ \\
\hline Q24 - It would not require a lot of $\mathrm{e} \square$ ort for students to learn how to use a mobile application designed for my class & $4,08 / 4,18$ & $1,01 / 1,10$ \\
\hline Q25 - It would be easy for students to engage in discussions using mobile application or website in mobile format & $4,08 / 3,97$ & $0,86 / 1,21$ \\
\hline
\end{tabular}

P- Portugal; S-Spain.

Table 5

Percentages of Yes and No responses of the 15 items of "Use of MD" (Q26).

\begin{tabular}{|c|c|c|c|}
\hline \multicolumn{3}{|c|}{ I would ask students to... } & \multirow{2}{*}{$\frac{(\%)(\mathrm{P} / \mathrm{S})}{29,7 / 36,4}$} \\
\hline 1 & Download application that help them learn new subjects & No & \\
\hline & & Yes & $70,3 / 63,6$ \\
\hline \multirow[t]{2}{*}{2} & Use MD to look up something that they didn't know or understanding during class & No & $27,0 / 30,3$ \\
\hline & & Yes & $73,0 / 69,7$ \\
\hline \multirow[t]{2}{*}{3} & Engage in social networking on their MD & No & $56,8 / 69,7$ \\
\hline & & Yes & $43,2 / 30,3$ \\
\hline \multirow[t]{2}{*}{4} & Write notes on their MD to remind themselves of an assignment & No & $29,7 / 36,4$ \\
\hline & & Yes & $70,3 / 63,6$ \\
\hline \multirow[t]{2}{*}{5} & Set alarms or reminders on their MD to help them remember an assignment or a test & No & $29,7 / 33,3$ \\
\hline & & Yes & $70,3 / 66,7$ \\
\hline \multirow[t]{2}{*}{6} & Text a classmate during class & No & $73,0 / 84,8$ \\
\hline & & Yes & $27,0 / 15,2$ \\
\hline \multirow[t]{2}{*}{7} & Text a classmate about the contents of the class & No & $54,1 / 66,7$ \\
\hline & & Yes & $45,9 / 33,3$ \\
\hline \multirow[t]{2}{*}{8} & Text a classmate about the professor's ability & No & $81,1 / 84,8$ \\
\hline & & Yes & $18,9 / 15,2$ \\
\hline \multirow[t]{2}{*}{9} & Text a classmate about the level of engagement in the class & No & $81,1 / 78,8$ \\
\hline & & Yes & $18,9 / 21,2$ \\
\hline \multirow[t]{2}{*}{10} & Take a picture or video with their MD that they could be used for an assignment & No & $27,0 / 42,4$ \\
\hline & & Yes & $73,0 / 57,6$ \\
\hline \multirow[t]{2}{*}{11} & Access an LMS (e.g. Moodle) on their MD & No & $21,6 / 21,2$ \\
\hline & & Yes & $78,4 / 78,8$ \\
\hline \multirow[t]{2}{*}{12} & Read a paper or assignment on their MD & No & $24,3 / 45,5$ \\
\hline & & Yes & $75,7 / 54,5$ \\
\hline \multirow[t]{2}{*}{13} & Use their MD as a study tool & No & $27,8 / 45,5$ \\
\hline & & Yes & $72,2 / 54,5$ \\
\hline \multirow[t]{2}{*}{14} & Play an educational game on their MD & No & $43,2 / 51,5$ \\
\hline & & Yes & $56,8 / 48,5$ \\
\hline \multirow[t]{2}{*}{15} & Use their MD with augmented reality as a learning tool & No & $48,6 / 57,6$ \\
\hline & & Yes & $51,4 / 42,4$ \\
\hline
\end{tabular}

In terms of Participation/Engagement, the overall mean value for each country $(4015$ (P)/3784 (S)) is above the neutral position of 3. It suggested that professors think that the students will have greater involvement and participation in activities (inside and outside the classroom) if they use their MD. It should be noted that these values are significantly higher in Portugal, with the opinions also being more consistent (variation coe $\square$ cient $9.76 \%(\mathrm{P}) / 11.36 \%(\mathrm{~S})$ ), and therefore mean is a representative measure.

As an example, professors strongly agree (mean $=4,59 / 4,33$ ) that students should be able to download mobile applications that could help them study $(\mathrm{Q} 20)$, and should be able to access LMS (mean $=4,59 / 4,30)(\mathrm{Q} 21)$. It should be noted that in both variables the opinions are consistent since standard deviations are reduced ( $\mathrm{sd}=0,55 / 0,85$ and $\mathrm{sd}=0,64 / 0,85$, respectively). In this dimension, for both countries, the lowest value (mean $=3,32 / 2,88, \mathrm{sd}=1,156 / 0,86$ ) for Q11 ("My students would spend more time on 
Table 6

Descriptive Statistics for each question of "Mobile use in the classroom" by country (Portugal/Spain).

\begin{tabular}{lc}
\hline Question & Mean (P/S) \\
\hline Q27 - I believe students can be taught how to appropriately use MD for learning & $4,19 / 3,85$ \\
Q28 - I believe students can be taught how to appropriately use MD for collaborative learning & $4,30 / 3,97$ \\
Q29 - I believe students can be taught how to appropriately use MD with augmented reality apps for learning & $0,81 / 1,03$ \\
Q30 - I believe students can be taught how to appropriately use MD with gamification apps for learning & $4,05 / 3,76$ \\
Q31 - I believe using mobile applications for learning in my classroom would benefit students & $4,05 / 3,76$ \\
Q32 - I think students would be more motivated to learn if they could use MD & $3,57 / 3,55$ \\
Q33 - Students would think is fun to use an interactive MD in my classroom & $3,76 / 3,58$ \\
Q34 - I would like my students to be able to use MD to access course contents and practical skills & $4,03 / 3,94$ \\
Q35 - I would like to learn more about m-learning, so that I can incorporate it in my classroom & $3,94 / 0,94$ \\
Q36 - I would like to learn more about m-learning, so that I can incorporate them into my lessons & $1,94 / 0,94$ \\
\hline
\end{tabular}

classwork if they could access materials anytime, anywhere on their $M D^{\prime \prime}$ ) shows a positive opinion for Portuguese professors than Spanish regarding the use of MD.

Looking carefully at Table 5 we can conclude that, once again, globally, when it comes to the matter of "Use of $M D$ " (Q26), in the sense, of what educational tasks professors ask students to do inside or outside the classroom, opinions about the use of MDs are identical for professors in both countries with the exception of items 14 and 15. For these items, although Yes/No percentages are almost equitable, around 50\%, there is a reversal in the opinion between Portuguese professors and Spanish professors, that is, whereas for Portuguese professors, "Yes" is predominant, for Spanish professors it is predominant "No". This fact evidences a greater predisposition of the Portuguese professors to ask the students to use their MD with augmented reality and gamification as a learning tool.

It is interesting to note that all items that refer to "text a classmate ..." (items 6-9) and "Engage in social networking" (item 3) predominate the "No" response in both countries, perhaps because it is considered, by the professors, a disturbing element, in the context of classroom. It is also important to highlight the high percentages of "Yes".

Table 6 shows the results for each question of "Mobile use in the classroom", analysis. The overall mean value for each country $(3.96(\mathrm{P}) / 3.76(\mathrm{~S}))$ is above the neutral position of 3. These values suggest that professors agree about students using MD in the classroom. It should be noted that these values are slightly higher in Portugal than in Spain, and opinions are equally consistent for professors in both countries (variation coe $\square$ cient $5.4 \%(\mathrm{P}) / 4.2 \%(\mathrm{~S})$ ), and therefore the average is a representative measure.

As can be observed, most professors agree (mean $=4,30 / 3,97)$ that students can be taught how to appropriately use MD for collaborativelearning $(\mathrm{Q} 28)$. Professors also somehow agree (mean $=3,57 / 3,55)$ that using mobile applications for learning in their classroom would benefit students (Q31).

Concerning question Q37, in order to incorporate m-learning in future classroom, 45,9\% (17/37) and 40,5\% (15/37) of the Portuguese professors said that will be able to e $\square$ ectively incorporate m-learning into their classroom without and with training, respectively and $13,5 \%$ do not think will be able to e $\square$ ectively incorporate m-learning into their classroom. By other hand, analyzing the corresponding values for Spanish professors we obtained the results 51.5\% (17/33) and 42.4\% (14/33) to e $\square$ ectively incorporate m-learning into their classroom without and with training, respectively, and only $6,1 \%$ do not think will be able to e $\square$ ectively incorporate m-learning into their classroom.

As we have hitherto verified that the opinion of the teachers of both countries is very similar to the questions asked in the questionnaire, we decided to see among them the most relevant ones (for the study of students using the MD) and their respective weights for the phenomenon under study. With this objective, given the multivariate nature of the analysis to be performed, we decided to opt for one of the most used methods, PCA (Principal Component Analysis).

As Cronbach's Alpha coe $\square$ cients for all dimensions shown a good intern consistency, we can continue the analysis by building four indices. For dimensions 2 ("Participation/Engagement") and 4 ("Mobile use in the classroom") the indices are constituted by the arithmetic average of the variables, "mean_D2" and "mean_D4", respectively For dimensions 1 ("Prior Knowledge") and 3 ("Use of MD") the indices are constituted by the sum of the items ("sum_D1" and "sum_D3") because items of these dimensions are on nominal scale $(0 / 1)$. In the case of using the arithmetic mean of the variables (instead of the sum), we could obtain values lower than 1 and assuch considered values missing by the software.

The above variables ("mean_D2", "mean_D4", "sum_D1" and "sum_D3") are considered relevant to our study, and two of the variables that integrate the last section Self-e $\square$ cacy ("Professor confident that can be able to do With a MD" and "Professor need to be able to"), namely "sum_5" and "sum_6", we decided to use the main component analysis with optimal scaling - CATPCA. This technique of multivariate exploratory analysis transforms a set of correlated variables into a smaller set of independent variables that are linear combinations of the original variables (principal components) (Pestana and Gageiro, 2014). For principal components retention criteria, the eigenvalue rule was superior to 1 and the Cronbach's alpha was measured for the internal consistency of each component.

Thus, according to the adopted rule it is possible to summarize the relational information among the variables in 2 principal components that explain approximately $74.8 \%$ of the total variance of the original six variables.

Table 7 shows the weights of each variable in each component, the percentage of variance explained and the internal consistency.

According to the weights of each variable in the 1st component, all variables are determinant because they present values above 0.5 in absolute value. However, to highlight the higher weights of the variables "Stud. Use MD" $(0.784)$, "Prof. Like/believe" $(0,753)$ 
Table 7

Principal components extracted (CATPCA).

\begin{tabular}{lll}
\hline \multirow{2}{*}{ Variables } & \multicolumn{2}{l}{ Components } \\
\cline { 2 - 3 } & 1 & 2 \\
\hline Stud. part./engage (mean_D2) & 0,674 & $-0,609$ \\
Prof. like/believe (mean_D4) & 0,753 & $-0,624$ \\
Prof. confident (sum_5) & 0,707 & 0,621 \\
Prof. needs (sum_6) & 0,606 & 0,045 \\
Prof. prior knowledge (sum_D1) & 0,631 & 0,663 \\
Stud. use MD (sum_D3) & 0,784 & $-0,004$ \\
Eigenvalue & 2,902 & 1,588 \\
\% of variance & $48,37 \%$ & $26,47 \%$ \\
Cronbach's alpha & 0,79 & 0,45 \\
\hline
\end{tabular}

and "Prof. Confident" (0.707). This reveals that the more confident teachers are with what they can do in classrooms with the MDs, the more they would like and believe that their students are able to do those activities using their MDs.

The 2nd component contrasts the variables "Prof. prior knowledge" $(0,663)$ and "Prof. confident" $(0,621)$ to the variables "Stud. part./engage" $(-0,609)$ and "Prof. like/believe" $(-0,624)$. This means that the more knowledge the teacher has of what he can do with the MDs, the more confidence he has in what he can do in the classroom. Moreover, the more knowledge the teacher has of what he can do with the MDs, the less his students' participation/involvement, as well as the less he believes in the ability of his students to use the MDs in their curricular activities.

Finally, a particularly useful graph is the bi-plot of object scores and component loadings (Fig. 5). Note that we use as a caption of the subjects (teacher), the variable Country (S-Spain; P-Portugal).

This graph shows the achievement of each individual (in this case the teacher) in each of the components. This type of representation also serves, for example, to identify the individuals (teachers) who fall outside the tendency of the rest. In addition, as we had seen with Table 7 it is possible to confirm which variables constitute each component and which are opposed to each other. In summary, analyzing the graph we can conclude on the relations between teachers and variables (that define the main components). As expected, it is notorious and independently of the country, that teachers have identical opinions (very similar scores) regarding the

issues analyzed. It is also possible to say that three teachers (two Portuguese and one Spanish) are not well integrated in relation to the others because they present clearly lower scores for the variables "Prof. Prior knowledge" and "Prof. Confident."

\section{Conclusions}

With the purpose of meeting the generations of students born with digital technology (Generation X), it is necessary to make an adaptation of the teaching-learning processes, in order accommodate new technologies. Therefore, it is critical to understand whether

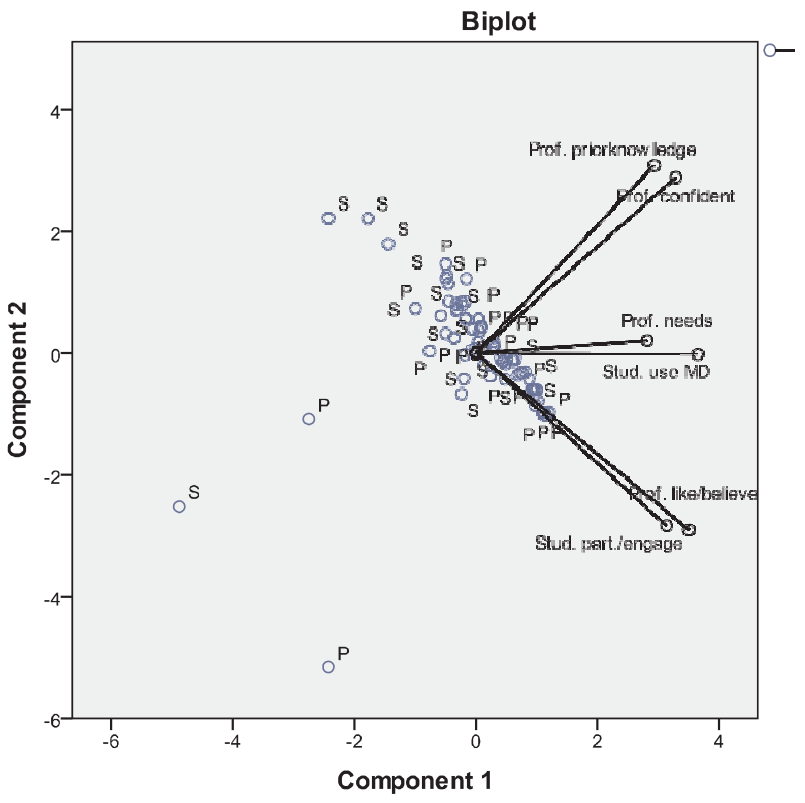

Fig. 5. Bi-plot defined by principal components 1 and 2 . 
users (students and professors) are receptive and aware to adapt to this new paradigm before deciding to implement teachinglearning methods based on technology in particular on mobile technology.

As a result, the successful integration of m-learning technologies in education require the perception of these technologies by professors, so it is possible to ask the question "How do professors percept m-learning?". In this context, the aim of this paper is to investigate the perception of professors in higher education, in the area of technology in IP in relation to m-learning, and to identify the needs of professors as they relate to mobile technologies and how they can be used to promote student's engagement inside and outside of the classroom.

As can be seen by the statistical analysis and discussed in the previous section, we concluded that the majority of IP professors have knowledge on how to perform the most trivial tasks with MDs. It is interesting to note that when questioned on the use of augmented reality applications and gamification results (items 10 and 11 of Q7) also still very high (> 60\%) for professors of both countries.

In terms of Participation/Engagement we concluded that professors think that their students will have greater involvement and participation in activities if they use their MD (inside and outside the classroom) although there is evidence that Portuguese professors have significantly more favorable (higher mean), and consistent (lower deviations) opinions.

When it comes to the matter of "Use of MD" (Q26), in the sense, of what educational tasks professors ask students to do inside or outside the classroom, opinions about the use of MDs are identical for teachers in both countries with the exception of items 14 and 15. There is evidence for a greater predisposition of Portuguese professors to ask students to use their MD with augmented reality and gamification as a learning tool, than Spanish teachers.

It is further noted that there is greater agreement on the Participation/Engagement, than the e $\square$ ective use of MDs in and out of the classroom for the students, from the perspective of professors.

As for the question "Mobile use in the classroom", we concluded that professors are in agreement about students using MD in the classroom. It should be noted that these values are slightly higher in Portugal and the opinions are equally consistent for teachers from both countries.

It is interesting to note that in order to incorporate m-learning in the future classroom, for both countries, the most voted option was "I will be able to $\square$ ectively incorporate mobile learning into my classroom without training".

Finally, in order to obtain the set of independent variables (main components) to determine the most relevant (variables) questions (for the study of students using the MDs) we performed the CATPCA. Since the main components are linear combinations of the original variables, they function as "indicators" that summarize the available information of the original variables. The use of this technique has enabled us not only to meet this objective but also to graphically represent teachers from both countries in the two main components retained.

This allowed us to conclude that: the more confident teachers are about they can do in classrooms with the MDs, the more they would like and believe that their students are able to do those activities using their MDs; The more knowledge the teacher has of what he can do with the more confident MD he has in what he can come to accomplish in the classroom. Moreover, the more confident teachers are about they can do in classrooms with the MDs, the more they think the participation/involvement of their students will be, and the less they believe in the ability to use the MDs in curricular activities by their students. With this representation we identify three teachers (two Portuguese and one Spanish) who do not belong to the tendency of the rest because they have a priori knowledge reduced in how to perform the most trivial tasks and little confidence (significantly low scores).

As a final conclusion it can be highlighted that in both countries the behaviors are identical in the receptivity of the use of the MD to increase the commitment of the students in activities inside and outside the classroom. It should be noted that, however, Portuguese teachers show slightly more optimism.

\section{Study limitations and future work}

The presented research has some limitations. Although the two selected countries (Portugal and Spain) in our point of view provided an interesting perspective on the current status of m-learning. However, the number of institutions chosen to conduct investigations was limited; although the institutions of the selection process have taken into account its importance in number of students and scientific and pedagogical quality, so their representativeness is significant.

The study does not reflect the most recent developments in the existing institutions of higher education. For instance, the impact of the use of such technologies in the actual performance of students, specifically within the collaborative learning model. Or, the perception of students concerning the utilization - past, present and future mobile devices in higher education in the context of teaching and learning, not assessing whether the use of such technologies actually contributes to stimulate interest in learning content. A broader view on mobile device usage and the comprehension of m-learning could be achieved by including a larger number of countries and higher education institutions.

Future research should expand to be able to perform a more accurate assessment of utilization trends of mobile devices in higher education, particularly in the implementation of collaborative learning model. The research presented took into account the coverage of Portugal and Spain, that is, the answers obtained come from higher education institutions covering the entire Iberian Peninsula. In this context, one of the lines of research to be explored in the future is to carry out comparative studies by region, in order to understand if there are differences between the various regions of the Iberian Peninsula. In addition, future research efforts should, on the one hand focus on data comparison between different countries and time-related changes and trends, and on the other hand we will expand the study for Ibero-American countries. Finally, the available academic and professional research on this topic is still rather limited, thereby providing an unexplored area for further research activities, as well as evaluate if there are differences in the 
attitudes regarding the adoption of m-learning, according to gender, age, and professional category.

\section{References}

Al-Emran, M., Shaalan, K., 2015. Learners and educators attitudes towards mobile learning in higher education: State of the art. In: Advances in Computing, Communications and Informatics (ICACCI). pp. 907-913.

Al-Hunaiyyan, A., Al-Sharhan, S., 2017. A new mobile learning model in the context of the smart classrooms environment: a holistic approach. Int. J. Interact. Mob. Technol. 11, 39-56.

Alwraikat, M., Tokhaim, H.Al, 2014. Exploring the potential of mobile learning use among faculty members. Int. J. 8, 4.

Andrews, T., Smyth, R., Tynan, B., Berriman, A., 2011. Mobile technologies and rich media: expanding tertiary education. Mob. Inf. Commun. Technol. Adopt. Dev. Ctries. E $\square$. Implic. 103.

Baran, E., 2014. A review of research on mobile learning in teacher education. Educ. Technol. Soc. 17, 17-32.

Barbaux, M.-T., 2006. From lifelong learning to m-learning. In: 13th International Conference ALT-C 2006: The next Generation. Edinburgh.

Barreh, K., Abas, Z., 2015. A framework for mobile learning for enhancing learning in higher education. Malaysian Online J. Educ. Technol. 3, 1-9.

Biloš, A., Turkalj, D, Kelić, I, 2017. Mobile learning usage and preferences of vocational secondary school students: the cases of Austria, the Czech Republic, and Germany. Naše Gospod. Econ. 63, 59-69.

Boticki, I., Baksa, J., Seow, P., Looi, C.-K., 2015. Usage of a mobile social learning platform with virtual badges in a primary school. Comput. Educ. 86, 120-136. http:// dx.doi.org/10.1016/j.compedu.2015.02.015.

Bower, M., Cram, A., Groom, D., 2010. Blended reality: issues and potentials in combining virtual worlds and face-to-face classes. In: Curriculum, Technology \& Transformation for an Unknown Future. Sydney. pp. 129-140.

Brand, J., Kinash, S., 2010. Pad-agogy: a quasi-experimental and ethnographic pilot test of the iPad in a blended mobile learning environment.

Campenhoudt, L.-V., Quivy, R., 2008. Manual de Investigação em Ciências Sociais. Gradiva Publicações.

Cheng, Y., 2015. Towards an understanding of the factors a $\square$ ecting m-learning acceptance: roles of technological characteristics and compatibility. Asia Pacific Manag. Rev. 20, 109-119. http://dx.doi.org/10.1016/j.apmrv.2014.12.011.

Cheon, J., Lee, S., Crooks, S.M., Song, J., 2012. An investigation of mobile learning readiness in higher education based on the theory of planned behavior. Comput. Educ. 59, 1054-1064. http://dx.doi.org/10.1016/j.compedu.2012.04.015.

Chu, H., 2014. Potential negative e $\square$ ects of mobile learning on students' learning achievement and cognitive load-a format assessment perspective. J. Educ. Technol. Soc. $17,332-344$

CISCO, 2017. VNI Global Fixed and Mobile Internet Tra $\square$ c Forecasts [WWW Document]. URL http://www.cisco.com/c/en/us/solutions/service-provider/visualnetworking-index-vni/index.html\#mobile-forecast.

Cochrane, T., Antonczak, L., 2014. Implementing a mobile social media framework for designing creative pedagogies. Soc. Sci. 3, $359-377$.

Corbeil, J., Valdes-Corbeil, M., 2007. Are you ready for mobile learning? Educ. Q. Mag. 30, 51-58.

Crompton, H., 2013. A Historical Overview of Mobile Learning: Toward Learner-centered Education. In: Handbook of mobile learning

Development, D. of E. and E.C., 2011. iPads for Learning In Their Hands Trial.

Diamandis, P., 2015. The World in 2025 [WWW Document]. URL http://78.46.45.106/ eira/index.php/talk-the-trends/item/2045-the-world-in-2025-by-peterdiamandis.

El-Hussein, M., Cronje, J., 2010. Defining mobile learning in the higher education landscape. Educ. Technol. Soc. 13, 12-21.

Emran, M. Al, Shaalan, K., 2014. E-podium Technology: A Medium of Managing Knowledge at Al Buraimi University College via M-learning., in: BCS International IT Conference.

Ergüt, A., Altıntas, G., 2012. Advantages of virtualization of cast in situ composite material production and testing stages in reverse engineering education. Contemp. Educ. Res. J. 2, 44-47.

Fiscarelli, S., Bizelli, M., 2013. Interactive simulations to physics teaching: a case study in Brazilian high school. Int. J. Learn. Teach. 5, 18-23.

Fogg, B., 2007. Mobile persuasion: 20 perspectives on the future of behavior change.

Fonseca, D., Martí, N., Redondo, E., Navarro, I., 2014. Relationship between student profile, tool use, participation, and academic performance with the use of Augmented Reality technology for visualized architecture models. Comput. Human Behav. 31, 434-445. http://dx.doi.org/10.1016/j.chb.2013.03.006.

García-Peñalvo, F.J., Hernández-García, Á., Conde, M.Á., Fidalgo-Blanco, Á., Sein-Echaluce, M.L., Alier-Forment, M., Llorens-Largo, F., Iglesias-Pradas, S., 2017. Enhancing Education for the Knowledge Society Era with Learning Ecosystems. In: García-Peñalvo, F.J., Hernández-García, A. (Ed.), Open Source Solutions for Knowledge Management and Technological Ecosystems. Advances in Knowledge Acquisition, Transfer, and Management (AKATM). IGI, IGI Global, Hershey PA, USA, pp. 1-24. doi: http://dx.doi.org/10.4018/978-1-5225-0905-9.ch001.

García, A.M.F., Esteban, A.P., 2011. Smart m-Learning Reusing Educational Contents. Springer, Berlin, Heidelberg. pp. 317-323. doi: http:/ /dx.doi.org/10.1007/978- 3642-19917-2_38.

Gartner, 2014. Gartner Says Worldwide Traditional PC, Tablet, Ultramobile and Mobile Phone Shipments to Grow 4.2 Percent in 2014 [WWW Document]. URL http:// www. gartner.com/newsroom/id/2791017.

Georgiev, T., Georgieva, E., 2004. M-learning-a New Stage of E-Learning. In: International Conference on Computer Systems and Technologies-CompSysTech. pp. 1-4. Gikas, J., Grant, M.M., 2013. Mobile computing devices in higher education: Student perspectives on learning with cellphones, smartphones \& social media. Internet High. Educ. 19, 18-26. http:/ / dx.doi.org/10.1016/j.iheduc.2013.06.002.

Holzinger, A., Nischelwitzer, A., Meisenberger, M., 2005. Lifelong-learning support by m-learning: example scenarios. eLearn 11.

Homan, S., Wood, K., 2003. Taming the mega-lecture: wireless quizzing. Syllabus Mag.

Hürsen, Ç., Özçınar, Z., Özdamlı, F., Uzunboylu, H., 2011. The communicative competences of students and teachers in di $\square$ erent levels of education in North Cyprus. Asia Pacific Educ. Rev. 12, 59-66. http://dx.doi.org/10.1007/s12564-010-9120-2.

Jackson, E., 2016. M-learning devices and their impact on postgraduate researchers scope for improved integration in the research community. Online J. New Horizons Educ. 6.

Jairak, K., Praneetpolgrang. P. 2009. An acceptance of mobile learning for higher education students in Thailand. Conf. eLearning..17, 361-368.

Johnson, L., Adams, S., Cummins, M., 2012. The NMC Horizon report, 2012 Higher Education Edition. Austin.

Johnson, L., Becker, S.A., Estrada, V., Freeman, A., 2014. The NMC Horizon Report: 2014 Library Edition. New Media Consort.

Ken, C., Yahaya, N., Ibrahim, N., Hasan, M., 2017. Review of Mobile Learning Trends 2010-2015: A Meta-Analysis. J. Educ. Technol. Soc. 20, 113-126.

Kinash, S., Brand, J., Mathew, T., 2012. Challenging mobile learning discourse through research: student perceptions of blackboard mobile learn and iPads. Australas. J. Educ. Technol. 28 .

Koc, M., 2013. Student teachers' conceptions of technology: a metaphor analysis. Comput. Educ. 68, 1-8. http:// dx.doi.org/10.1016/j.compedu.2013.04.024.

Kok, I., 2012. Explicit strategy training and english language proficiency. Glob. J. Foreign Lang. Teach. 2, 33-38.

Land, S.M., Zimmerman, H.T., 2015. Socio-technical dimensions of an outdoor mobile learning environment: a three-phase design-based research investigation. Educ. Technol. Res. Dev. 63, 229-255. http://dx.doi.org/10.1007/s11423-015-9369-6.

Levy, P., 1996. O que é o virtual. São Paulo: Ed.

Liaw, S.-S., Hatala, M., Huang, H.-M., 2010. Investigating acceptance toward mobile learning to assist individual knowledge management: based on activity theory approach. Comput. Educ. 54, 446-454. http:// dx.doi.org/10.1016/j.compedu.2009.08.029.

Matias, A., Wolf, D., 2013. Engaging Students in Online Courses Through the Use of Mobile Technology, Ncreasing Student Engagement and Retention Using Mobile Applications: Smartphones. Skype and Texting Technologies. Emerald Group Publishing Limited.

Mcconatha, D., Praul, M., 2008. Mobile learning in higher education: an empirical assessment of a new educational tool. TOJET Turkish online J. Educ. Technol. 7. 
Miangah, T., Nezarat, A., 2012. Mobile-assisted language learning. Int. J. Distrib. Parallel Syst. 3, 309.

Mirski, P., Abfalter, D., 2004. Knowledge Enhancement on Site-Guests' attitudes towards m-Learning. In: Proceeding of the Information and Communication Technologies in Tourism. Cairo, pp. 592-600.

Moreira, F., Ferreira, M.J., Santos, C.P., Durão, N., 2016. Evolution and use of mobile devices in higher education: a case study in Portuguese higher education institutions between 2009/2010 and 2014/2015. Telemat. Informatics. http://dx.doi.org/10.1016/j.tele.2016.08.010.

Moreira, F., Pereira, C.S., Durão, N., Ferreira, M.J., 2017. Mobile Learning in Portuguese Universities: Are Professors Ready? Springer, Cham. pp. 887-896. doi: http:/ / dx.doi.org/10.1007/978-3-319-56538-5_88.

Morris, D., 2010. E-confidence or incompetence: are teachers ready to teach in the 21st century. World J. Educ. Technol. 2, $142-155$.

Mostakhdemin-Hosseini, A., Tuimala, J., 2005. Mobile learning framework. In: Proceedings IADIS International Conference Mobile Learning. pp. 203-207.

Newhouse, C., Williams, P., Pearson, J., 2006. Supporting Mobile Education for Pre-Service Teachers. Australas. J. Educ. Technol. 22.

Norris, C., Soloway, E., Trentin, G., 2013. A conclusive thought: the opportunity to change education is, literally, at hand. Using Netw. 209-220.

O'Malley, C., Vavoula, G., Glew, J., Taylor, J., Sharples, M., 2005. Guidelines for learning/teaching/tutoring in a mobile environment.

Oinas-Kukkonen, H., Harjumaa, M., 2008. A systematic framework for designing and evaluating persuasive systems. In: International Conference on Persuasive. pp. 164-176.

Oulasvirta, A., Rattenbury, T., Ma, L., Raita, E., 2012. Habits make smartphone use more pervasive. Pers. Ubiquitous 16, 105-114.

Ozdamli, F., 2012. Pedagogical framework of m-learning. Procedia - Soc. Behav. Sci. 31, 927-931. http:// dx.doi.org/10.1016/j.sbspro.2011.12.171.

Ozdamli, F., Uzunboylu, H., 2015. M-learning adequacy and perceptions of students and teachers in secondary schools. Br. J. Educ. Technol. 46, 159-172. http:// dx. doi.org/10.1111/bjet.12136.

Papert, S., 1994. Children's Machine: Rethinking School in the Age of the Computer. Basic Books, New York, NY.

Papoutsi, C., Drigas, A., 2017. Empathy and mobile applications. J. Interact. Mob. Technol. 11, 57-66.

Park, S., Nam, M., Cha, S., 2012. University students' behavioral intention to use mobile learning: Evaluating the technology acceptance model. Br. J. Educ. 43, $592-605$.

Park, Y., 2011. A pedagogical framework for mobile learning: Categorizing educational applications of mobile technologies into four types. Int. Rev. Res. Open Distrib. Learn. 12, 78-102.

Pestana, M.H., Gageiro, J.N., 2014. Análise de dados para Ciências Sociais. A complementaridade do SPSS, 6a Edição. ed. Edições Sílabo, Lisboa.

Quinn, C., 2000. mLearning: Mobile, wireless, in-your-pocket learning. LiNE Zine 2006.

Research, E.C. for A., 2012. ECAR study of undergraduate students and information technology.

Royle, K., Stager, S., Traxler, J., 2014. Teacher development with mobiles: comparative critical factors. Prospects 44, 29-42. http:/ / dx.doi.org/10.1007/s11125-0139292-8.

Sabah, N.M., 2016. Exploring students' awareness and perceptions: Influencing factors and individual di $\square$ erences driving m-learning adoption. Comput. Human Behav. 65, 522-533. http://dx.doi.org/10.1016/j.chb.2016.09.009

Schuck, S., Aubusson, P., Kearney, M., 2013. Mobilising teacher education: a study of a professional learning community. Teach. Dev. 17, 1-18.

Severino, S., Messina, R., 2010. Analysis of similarities and di $\square$ erences between on-line and face-to-face learning group dynamics. World J. Educ. Technol. 1, 124-

141. Sharples, M., 2007. A Theory of Learning for the Mobile Age. Learning Science Research Institute, Nottingham.

Snell, S., Snell-Siddle, C., 2013. Mobile learning: the e $\square$ ects of gender and age on perceptions of the use of mobile tools. In: The Second International Conference on Informatics Engineering \& Information Science (ICIEIS2013). pp. 274-281.

Spiegel, A., Rodríguez, G., 2016. Students at University have Mobile Technologies. Do they do m-learning? Procedia - Soc. Behav. Sci. 217, 846-850. http:/ / dx.doi. org/10.1016/j.sbspro.2016.02.006.

Taleb, Z., Ahmadi, A., Musavi, M., 2015. The e $\square$ ect of m-learning on mathematics learning. Procedia - Soc. Behav. Sci. 171, 83-89.

Tayfun, Y., Arzu, O., 2012. Utilization of distance learning technologies in postgraduate architectural education. Glob. J. Inf. Technol. 2, 7-14.

The World Bank Institute, 2012. Behavioral change using technology [WWW Document]. URL http://wbi.worldbank.org/wbi/content/behavioral-change-usingtechnology.

Traxler, J., 2007. Defining, discussing and evaluating mobile learning: the moving finger writes and having writ.... Int. Rev. Res. Open Distance Learn. 8, 9-24.

Uzunboylu, H., Ozdamli, F., 2011. Teacher perception for m-learning: scale development and teachers' perceptions. J. Comput. Assist. 27, 544-556.

Valero, C., Redondo, M., Palacín, A., 2012. Tendencias actuales en el uso de dispositivos móviles en educación. La Educ. Digit. Mag. 147, 1-21.

West, M., Ei, C., 2014. Reading in the Mobile Era: A Study of Mobile Reading in Developing Countries. UNESCO.

World Economic Forum, 2016. New Vision for Education: Fostering Social and Emotional Learning Through Technology.

Yusri, I., Goodwin, R., Mooney, C., 2015. Professors and mobile learning perception: towards a conceptual model of mobile learning for training. Procedia - Soc. Behav. Sci. 176, 425-430.

Zhuang, S., Hu, L., Xu, H., Tian, Y., 2011. M-Learning Design Based on Personal Knowledge Management. In: Information Management, Innovation Management and Industrial Engineering (ICIII). IEEE, pp. 135-138. 